\title{
Aging Labor and Japanese Industry Performance: Lessons for Indonesia Policies
}

\author{
Indri Dwi Apriliyanti \\ Ph.D. candidate in International Management, School of Business and Law, Universitetet i Agder, Norway \\ (email: indri.apriliyanti@uia.no)
}

\begin{abstract}
This study analyzes the labor input factor that determines and shapes output generation in Japan. It hypothesizes that labor input contributes to the development of output growth in Japanese industries. In addition to that, it is hypothesized that moderator variable which is represented by numbers of aging labor can either stimulate or weaken the output generation. Hypotheses are tested using the data obtained from the Research Institute of Economy, Trade, and Industry (RIETI) Japan Industrial Output (JIP) Database 2011 and Japan Statistics Official within period 1970 to 2008. A multiple regression analysis, a manova and a hierarchical multiple regression analysis are conducted. Similar to expectation, aging labor has a negative moderating effect on labor-intensive industry; meanwhile aging labor has a positive moderating effect on capital-intensive industry. Not only does this study provide thorough knowledge towards output generation in Japan, but it also provides substantial lessons for Indonesia, particularly to enhance the industrial policy regarding the aging labor.
\end{abstract}

\section{Keywords:}

labor input; aging labor; output; Japanese industry

\section{Introduction}

The tragedy of the atomic bomb in Hiroshima and Nagasaki had led Japan to total devastation. This also brought about destruction in Japan's economy. The impressive part of Japan's post-war story, however, became the power of Japan to rebuild its economy. It was proven by the ability of Japan's economy to obtain high rates of growth in 1960. Prior to that achievement, the Japanese Government and Japanese corporate executives in 1950 had agreed upon cooperation to collaborate in growing the economy through industrialization. The rapid movement toward industrialization transformed Japan from a peasant society to an industrial powerhouse (Krugman, 1994). This rapid transformation prompted a question about how this country drove rapid economic development.
The shift of a country from one economic development stage to another has been becoming an influential issue in the academic world. Numerous discussions on Japan's economic growth are as a result focused on examining the drivers behind the expansion of industrial production. Coccia (2009) argues that the function of output can be the key to investigating the discourse about industrial production as the main determinant behind Japan's economic miracle. Notably, output is an essential factor in contributing to Gross Domestic Product (GDP) (Fujiwara, Iyetomi, Ikeda, \& Souma, 2009) as it enables the exaggeration of economic growth in a country.

A critical part of output deliberation is to examine the correlation between output function and environment. It is noteworthy to mention that the most critical part in output 
discussion is analysis of how the surroundings can influence output. At this point, it is important to consider that the production process is not simple or free from such an influence. The output is not solely a result of a set of inputs in a production process. In essence, it is also a result of a series of a firm's choice and decision toward input investment. Firm executives' decisions are highly derived from the environment as output generation does not occur in an empty environment. It is not surprising then that there is concern that the environment may constrain the future of output growth. Particularly, the environment has the power to affect the firm executives in determining the inputs in the production process. From this aspect, the discussion about the output function is carried out in a more constructive and comprehensive way.

As Japan encounters the growth of its aging population and aging labor force, output may be considered as a result of this phenomenon. The percentage of the elderly in Japan's population is the highest in the world (Statistic Bureau of Japan, 2012). The increase in life expectancy and the decline in population growth are two reasons for the shrinkage of the labor market. This demographic change has altered the labor structure. Japanese firms are filled with aging labor. Under conditions in which human capital plays a focal role in productivity, the growth of aging labor is a substantial concern for firms. The rationale for this argument is that aging labor, to some extent, can affect the work-effectiveness due to lost time through absenteeism, illness or early retirement (Shephard, 2000).

Scholars argue that older labor differs from younger labor substantially to the point that it may affect their output (Verhaegen \& Salthouse, 1997). Under conditions where the main production bottleneck is human output, it is then crucial to focus on the input of human capital. It is believed that age-related changes in physical and mental health condition are inevitable and might lead to the diminishing of output at work (Silverstein, 2008). Thus, any immediate loss of time due to chronic illness, absenteeism, and the long-term loss of human capital due to premature death may become major factors for why the discussion about aging labor is important. On the other side, several scholars stated that aging labor is not a problem as older laborers are associated with having an abundance of experiences through a learning by doing effect (Malmberg, Lindh, \& Halvarsson, 2008). The existence of two opposite hypotheses on the effect of aging labor on output, but not mutually exclusive, obviously needs a more thorough empirical study. Even though the hypotheses are competing, it is possible that both hypotheses are true. Furthermore, these two opposite hypotheses need to be examined further in two different types of industries labor-intensive industries and capital-intensive industries.

\section{Literature Review}

This literature review proposes the argument that output of industry is affected by labor productivity and the age of laborers mediates such relationship. According to Tangen (2002), output is a result of a set of inputs, or, in other words, the inputs invested in production can generate the output. The output thus is related to the employment and the availability of resources. As argued by Tangen, it can be drawn that output is also affected by the labor condition, which plays one of the most important inputs in production function (Douglas, 1976). However, the condition of labor plays the role of a moderator because it does not directly affect output.

To the best of the writer's knowledge, research studies on the effect of the laborer's age on output are rare. Conversely, research on the correlation between laborer's age and economic growth or the relation between population growth and labor input (Beaudry, Collard, \& Green, 2005) are immense (Bloom, Canning, 
\& Sevilla, 2001). It is argued that depreciation is applied not only to physical capital assets but also to human capital or labor. One of the factors triggering the depreciation is derived from aging (Remery, Henkens, Schippers, \& Ekamper, 2003). One faction perceives that the composition of working-age labor ranging from 30 to 50 years old can increase output as those working-age laborers are considered more productive than old or young laborers. On the other side, a research study of Horndal steel in Central Sweden argues that the older laborers are more productive than young laborers. The argument shows that older workers are productive as they represent the immense experience and knowledge by undergoing a learning-by-doing system (Prskawetz, Fent, \& Guest, 2008). As a result, this faction considers that aging labor is not a problem for output. The different viewpoints between these two factions are not mutually exclusive though. Broadly, the divergence between these standpoints shows that the age of the laborer possibly affects output in two ways.

\section{Interrelationship among Aging Labor, Labor Input, and Output}

The effect of age structure on labor input has become the topic in many research studies (Feyrer, 2007). Nonetheless, the effect of aging labor on output is under debate amongst scholars. Park and Shin (2012) argue aging laborers tend to have immense knowledge and experience obtained from their lifetime of employment, while younger labors have a tendency to be more physically stronger. Börsch and Supan (2003) and Skirbekk (2004) argue that aging laborers should be discussed in a clearer and more balanced context in order to determine whether the laborers produce better input or not. The authors state that when laborers are educated and obtain job training during their employment, these will compensate their age as they still generate good productivity or what Becker (1962) says that aging labors in view of their experiences are more productive. In alignment with this argument, Skirbekk (2008) added that experiences could enhance the output through the experience accumulation. Both Börsch and Supan (2003) and Skirbekk (2004) highlight the importance of investing in human capital to handle the possible negative effects of aging laborers.

On the other hand, another faction of scholars is in agreement that aging labor is highly associated with the diminishing of abilities; thus, making them less productive compared to younger laborers (Skirbekk, 2004). From this argument, Skirbekk further stated that aging labor could show a decline in performance concerning work-related abilities. Older labor is sensitive towards a more negative and distracted environment (Prskawetz, 2006). Thus, the younger laborers are considered to be more productive for being able to spend more hours at work and to be more concentrated on the job compared to older ones (Tang \& MacLeod, 2006).

Based on the arguments above, this research proposes that in a labor-intensive industry excessively emphasizing on manpower, the work environment requires laborers to have high mobility and pushes them to be engaged in physically intense work-related tasks. Here, younger laborers thus can be more productive than older ones. On the other hand, in a work environment that demands the skill, knowledge, and competence of labors - rather than physical power, older laborers embedded with the accumulation of knowledge and experiences can be more productive than younger ones. This type of environment can be attained in a labor-intensive industry. This industry markedly emphasizes the aggregate of know-how, which reflects the depth of stock of knowledge. Therefore the hypotheses are:

$\mathrm{H}_{1}$ : aging labor has a negative moderating effect on a relationship between labor input and output in a labor-intensive industry. 
$\mathrm{H}_{2}$ : aging labor has a positive moderating effect on the relationship between labor input and output in a capital-intensive industry.

\section{Methods}

This section elaborates the research model, definition of variables, measurement of variables, data sources, and data analysis. This study used a quantitative method to answer the two hypotheses. The study is based on longitudinal data collected from the Japanese government for the period 1970 to 2008 .

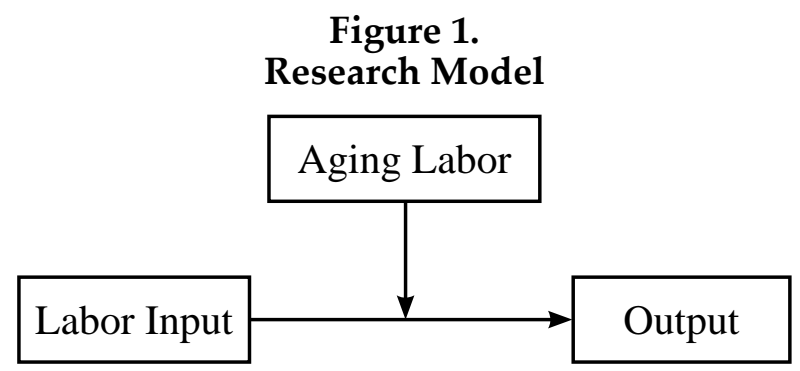

Source: Author.

\section{Definition of Variables}

Output is defined as the relation of produced goods or produced services to input (resources which are consumed and utilized) in production function process. It, nevertheless, is not only defined so but also as the added value that can be incorporated into goods or services (Tangen, 2002). Furthermore, the definition of labor input is an index that is utilized as an ideal measure of the working force (Cobb \& Douglas, 1928). A common measurement for analyzing labor productivity or labor input is by man-hour indicator (Disney, Haskel, \& Heden, 2003). Manhour is calculated based on the average number of hours in a standardized annual work. Commonly, it is used as an indicator to denote the labor input (Disney et al., 2003). Lastly, considering the improvement in life expectancy influences the decision of labor to remain work longer. Aging labors are those aged 55 or above in which the number of these labors becomes the only one parameter to denote the aging labor (Bureau of Labor Statistics, 2012).
A dependent variable refers to output, the indicator of which is value added in current prices represented in million yens. The independent variables, meanwhile, are labor input and aging labor in which the indicators of them are man-hours in annual standard per 1,000 workers and the number of workers over 55 years old, respectively.

\section{Measurement of Variables}

According to microeconomic theory, industry's production function is defined by the output produced from a given of factor, such as labor input. It is assumed that the input is applied and is able to produce output, which appears at an impending point in time (Aigner \& Chu, 1968). The production function is a result of constant profit per unit produced by a unit of labor input, i.e., the production function can be termed as the profit (per labor) production function (Sato, 1970). Aigner and Chu (1968) argue that each industry has different labor inputs represented by different labor productivity. In the classic production function, Solow (1956) and Swan (1956) posit that an aging population affects the labor input. Further, Christiaans (2003) state that age affects labor productivity; therefore, labor input is mixed or not homogenous as it produces different productivities depending on laborers' age.

One model of production function is used to examine the role of labor input to output. However, this output function model has a moderating variable called as aging labor. $P$ is the measure of industry output, $i$ is industry, $t$ at time, and $L$ denotes the number of manhours performed. Meanwhile, the moderating variable is AL representing aging labor. Again, $A$ is a constant and $\beta$ and $\delta$ are the elasticity of output with respect to labor and aging labor.

$$
\begin{aligned}
& P_{i t}=L_{i t}^{\beta} A L_{i t}^{\delta} \\
& \log (\mathrm{P})=\mathrm{A}+\beta \log (\mathrm{L})+\delta \log (\mathrm{AL})
\end{aligned}
$$


Industry Coverage, Time Data, and Data Sources

This study involves ten fields of industry as presented below.

Table 1.

Ten Field of Japanese Industries

\begin{tabular}{|c|c|c|}
\hline No & Industry & Sector \\
\hline 1 & $\begin{array}{l}\text { Transport and } \\
\text { Telecommunication } \\
\text { Service Industry }\end{array}$ & $\begin{array}{l}\text { Transport (Railway, Road } \\
\text { Transportation, Water } \\
\text { Transportation and Air } \\
\text { Transportation) } \\
\text { Communication } \\
\text { Postal Activities }\end{array}$ \\
\hline 2 & $\begin{array}{l}\text { Chemical Products } \\
\text { industry }\end{array}$ & $\begin{array}{l}\text { Chemical Fertilizers } \\
\text { Basic Inorganic Chemicals } \\
\text { Basic Organic Chemicals } \\
\text { Organic Chemicals } \\
\text { Chemical Fibers } \\
\text { Miscellaneous Chemical } \\
\text { Products }\end{array}$ \\
\hline 3 & $\begin{array}{l}\text { Construction } \\
\text { Industry }\end{array}$ & Construction \\
\hline 4 & $\begin{array}{l}\text { Petroleum Products } \\
\text { Industry }\end{array}$ & Petroleum Products \\
\hline 5 & $\begin{array}{l}\text { Rubber Products } \\
\text { Industry }\end{array}$ & Rubber Products \\
\hline 6 & $\begin{array}{l}\text { Pharmaceutical } \\
\text { Products Industry }\end{array}$ & Pharmaceutical Products \\
\hline 7 & $\begin{array}{l}\text { Iron and Steel } \\
\text { Products Industry }\end{array}$ & $\begin{array}{l}\text { Pig Iron and Crude Steel } \\
\text { Miscellaneous Iron and } \\
\text { Steel }\end{array}$ \\
\hline 8 & $\begin{array}{l}\text { Pulp and Paper } \\
\text { Products Industry }\end{array}$ & $\begin{array}{l}\text { Pulp, Paper and Coated } \\
\text { and Glazed Paper } \\
\text { Paper Products } \\
\text { Printing, Plate Making for } \\
\text { Printing and Bookbinding }\end{array}$ \\
\hline 9 & Mining Industry & Mining Products \\
\hline 10 & $\begin{array}{l}\text { Motor Vehicles } \\
\text { Products Industry }\end{array}$ & $\begin{array}{l}\text { Motor Vehicles } \\
\text { Motor Vehicles Parts and } \\
\text { Accessories }\end{array}$ \\
\hline
\end{tabular}

Source: JIP database.

The selection of Japanese industries is based upon the argument that industrial transformation in a country which undergoes a shift of economic structure may have impacted on the output generation. For example, Japan is now facing a shifting of the backbone of its industrial development. Previously, manufacturing industry became output growth-enhancers, but the service sector is now being a new output growth booster (Gray, 2004).
The declining role of the manufacturing sector in generating output growth draws attention to the power of the service sector as a prominent contributor to GDP in many industrialized countries. Based on this argument, industry which is rooted in a non-manufacturing sector should be taken into account in the research (Timmer, 2002). Particularly, the shift of leading industry will affect the number of capital, both tangible and intangible, and labor needed. Moreover, the shift itself will alter the total industry's output.

Previously, several studies on the discussion of output growth have been solely focused on the manufacturing sector (Fujiwara et al., 2009). In response to this, this study is purposely to examine the behavior of output in four different sectors-service, manufacturing, construction, and mining. Here, service sector includes transport and telecommunication service industry. Further, the construction sector and mining sector represent their industries respectively. Lastly, the manufacturing sector industries include several products such as petroleum, rubber, chemical, pharmaceutical, iron and steel, pulp and paper, and motor vehicles. The decision to select these industries was based on the presence of data and the relative importance of those industries in Japan's economy. The analysis towards the shape of the distribution of output across industries will uncover the origin of output generation. This study offers a critical insight into the output growth across industries. It is deemed critical in view of the inadequacy of information about what the output in different industries comprises.

The categorization of industries is based on the Japanese industrial classification system as published by the Japanese Government. All necessary variables can be collected because the Japanese Government and related research institutes have gathered the data over a long period. Here, this study has collected data from 1970 to 2008. The analysis, in turn, has 
been restricted to this period in consideration of the reliance upon the availability of the data in several data sources used.

There are two sources used to collect the variable data - Research Institute of Economy, Trade, and Industry (RIETI) Japan Industrial Productivity (JIP) Database 2011 and Japan Statistics Official. JIP database is compiled as one of the RIETI's research project. RIETI is a Japanese Government agency. Meanwhile, the Japan Industrial Productivity Database 2011 (JIP Database 2011) is an extended version of the JIP Database 2010 compiled in a collaborative effort between RIETI and Hitotsubashi University's Global COE Hi-Stat Program.

\section{Data Analysis Methods}

Data analysis in this study was conducted using five statistical methods. Interpolation is the first method used in view of the data limitation for moderating variables, including the ratio of workers over 55 years old. Japan's official statistics, in this case, only publishes these data every five years and three years. Considering this issue, the data are then interpolated for the intervening years. Ratio to number method becomes the following used method. It is utilized as the presence of ratio in aging labor variables essentially to be transformed into number of workers over 55 years old. Transformation is needed to make the number of aging labor similar to the other data.

The third method is natural logarithm applied to all data. Natural logarithm is employed as an in time series analysis, commonly used to transform all variables by undertaking natural logarithm (Beck \& Katz, 1995). Particularly in Cobb Douglas function, all variables that have the trend of exponential growth are transformed by employing natural logarithm in order to obtain linearity in logs (Gujarati, 2006). The utilization of natural logarithm is because coefficients on the naturallog scale are directly interpretable as some approximate proportional differences (Gelman \& Hill, 2007). Thus, undertaking the natural logarithm of a time series allows the researcher to continuously calculate the compounded return of the time series as the difference between two points of the time series.

The fourth method is multiple regression analysis. This is carried out to understand the relationship between independent and dependent variables, and to explore the forms of this relationship. Regression analysis can be used to infer a 'possible' causal relationships between the independent and dependent variable in some restricted circumstances (Armstrong, 2011). Furthermore, it is one of the most widely used statistical tools now that it can provide a number of simple methods for establishing a functional relationship among variables as stated by Chatterjee, Hadi, and Price (2000). The last method is a hierarchical multiple regression method that is depleted to observe the effect of the labor input on output with the moderating effects of aging labor.

\section{Result}

\section{Interrelationship among Aging Labor, Labor Input, and Output}

The industry output is partly built upon the performance of labors represented in number of work hours carried out by laborers. Nonetheless, each laborer has his or her limitation in executing the work, which, in turn, can affect the number of work hours and consecutively alter the output. For that reason, understanding the dynamics of output from laborers is deemed an important element in the output discussion. A number of previous research studies have shown that the increase of aging labor may reduce the quantity of labor input. In Japan, it is becoming a concern as the Japanese Government is worried about the influence of aging labor via labor input on industry's output. Nonetheless, the regression analysis shows different results across two different industries-labor intensive industry 
and capital intensive industry. The impressive findings reveal the distinctive result of each industry towards the productivity of aging labor. In this case, the role of aging labor is highly influenced by the characteristics of the industry. Each characteristic of industry determines the requirement needed for labor. In a word, aging labor in each industry draws some different impacts on the behavior of output generation. For examining the categorization of each industry as to whether they are grouped into capital-intensive or labor-intensive, the author followed the categorization of RIETI Japan from where the data was sourced.

\section{Interrelationship among Aging labor, Labor Input, and Output in Labor-Intensive Industry}

In consideration of testing the direct effect of the aging labor on labor input, a regression analysis was conducted in each industry that has been acknowledged as a labor-intensive industry.

Table 2.

Aging Labor in Labor Intensive Industry Model Regression Result

\begin{tabular}{clccc}
\hline No & \multicolumn{1}{c}{ Industry } & R & $\begin{array}{c}\text { R } \\
\text { Square }\end{array}$ & $\begin{array}{c}\text { Adjusted } \\
\text { R Square }\end{array}$ \\
\hline 1 & Transport and & .981 & .962 & .959 \\
& Telecommunication & & & \\
& Service Industry & & & \\
2 & Construction Industry & .972 & .944 & .939 \\
3 & Mining Industry & .925 & .856 & .844 \\
4 & Motor Vehicles & .973 & .946 & .941 \\
& Products Industry & & & \\
\hline
\end{tabular}

Source: Statistics result.
As seen from the regression table above, the model of aging labor as a moderator of the relationship between labor input and output demonstrates a good model fit. It can be proven from the scores of R, R square, and adjusted $R$ square that pass the rule of thumb.

As shown by the regression computation above, four (as indicated in table 3) industries have a negative and significant relationship. Thus, it can be summed that aging labor has a negative moderating effect on the relationship between labor input and output. In other words, in a labor-intensive industry, older laborers are less productive than the younger ones.

Industries identified as labor-intensive industries include those in transport and telecommunication service, construction, mining, and motor vehicles products. This can be understood in that the transport and telecommunication service industry rely highly on its younger labors (Selmer, 2001). Concurrently, construction industry and mining industry are characterized by a highly regulated health and safety environment; thus, the issues related to age, health, and safety precisely can affect the output in these industry sectors (Abdel-Wahab \& Vogl, 2011). Meanwhile, the motor vehicle industry is acknowledged as a labor-intensive industry. Ito \& Lechevalier (2009) claim that the motor vehicle industry has a large increase in terms of labor input. The tasks involved in motor vehicle production emphasize more on the manual labor-related works or more physical

Table 3.

Aging Labor in Labor Intensive Industry Analysis Regression Result

\begin{tabular}{clccc}
\hline No & \multicolumn{1}{c}{ Industry } & $\begin{array}{c}\text { Coefficient } \\
\text { (Beta Value) }\end{array}$ & $\mathbf{t}$ Value & $\begin{array}{c}\text { p-Value } \\
\text { (Significance) }\end{array}$ \\
\hline 1 & $\begin{array}{l}\text { Transport and telecommunication service } \\
\text { industry (Transport and Communication) }\end{array}$ & -.171 & -3.674 & .001 \\
2 & & & \\
2 & Construction & -.159 & -3.307 & .002 \\
3 & Mining Industry & -.411 & -4.383 & .000 \\
4 & Motor Vehicles Products Industry & -.334 & -8.231 & .000 \\
\hline
\end{tabular}

Source: Statistics result. 
works requiring highly consistent precision and accurate measurement. Based on these requirements in work environment, the preference of labor in motor vehicles products industry is then centered on young laborrather than old labor. This claim is strengthened by Imagawa (2008), who affirms that the motor vehicle industry is one of few industries in Japan with the highest net job gains. In general, it is understood that the ability of laborers to work in a labor-intensive industry is admittedly essential to output. Thus, in laborintensive industries, aging labor is associated with the decline of work performance, which is connected to work-related competencies (Skirbekk, 2008).

Interrelationship among Aging Labor, Labor Input, and Output in Capital-Intensive Industry

In an attempt to obtain information on the correlation between aging labor, labor input, and output, a regression is applied to six industries, which are recognized as capitalintensive industries. Those identified industries rely on both their capital and eminently skilled labors in creating and generating output. Further, the factor that determines the ability of aging labor in attaining output is relied on the concept of lifetime employment considering that a capital-intensive industry largely employs highly skilled labors (Carree, Klomp, \& Thurik, 2000).
Table 4.

Aging Labor in Capital Intensive Industry Model Regression Result

\begin{tabular}{clccc}
\hline No & \multicolumn{1}{c}{ Industry } & R & $\begin{array}{c}\text { R } \\
\text { Square }\end{array}$ & $\begin{array}{c}\text { Adjusted R } \\
\text { Square }\end{array}$ \\
\hline 1 & Chemical Products & .952 & .907 & .899 \\
2 & $\begin{array}{l}\text { Petroleum Industry } \\
\text { Products }\end{array}$ & .964 & .930 & .924 \\
3 & Rubber Products & .969 & .938 & .933 \\
4 & $\begin{array}{l}\text { Pharmaceutical } \\
\text { Products }\end{array}$ & .924 & .854 & .842 \\
5 & $\begin{array}{l}\text { Iron and Steel } \\
\text { Products Industry }\end{array}$ & .696 & .484 & .440 \\
6 & $\begin{array}{l}\text { Pulp and Paper } \\
\text { Products Industry }\end{array}$ & .968 & .938 & .932 \\
\hline
\end{tabular}

Source: Statistics result.

The regression table above shows that the model fit from all of these industries portrays a good score. Thus, the model of aging labor as a moderator of the relationship between labor input and output demonstrates a good model fit. Table 4 below lists the result of regression to represent the coefficient of moderator variable in each industry.

As listed from the regression computation above, five out of six industries demonstrate a significant positive moderating effect on the relationship between labor input and output in capital-intensive industries. Based on this computation, the assumption that aging labor is more fruitful in capital-intensive industry is partially confirmed-meaning that older laborers are more productive than younger ones in product industries of chemical,

Table 5.

Aging Labor in Capital Intensive Industry Analysis Regression Result

\begin{tabular}{clccc}
\hline No & \multicolumn{1}{c}{ Industry } & $\begin{array}{c}\text { Coefficient } \\
\text { (Beta Value) }\end{array}$ & t Value & $\begin{array}{c}\text { p-Value } \\
\text { (Significance) }\end{array}$ \\
\hline 1 & Chemical Products & .546 & 10.454 & .000 \\
2 & Petroleum Products Industry & .191 & 3.788 & .001 \\
3 & Rubber Products & .657 & 12.060 & .000 \\
4 & Pharmaceutical Products & .097 & 1.301 & .202 \\
5 & Pulp and Paper Products Industry & .628 & 11.601 & .000 \\
6 & Iron and Steel Products Industry & .463 & 3.372 & .002 \\
\hline
\end{tabular}

Source: Statistics result. 
petroleum, rubber, iron and steel and pulp and paper. However, in pharmaceutical products industry, the computation does not show any significant relationship although it shows positive direction.

According to Park \& Shin (2012), lifetime employment is equal to the accumulation of an in intangible investment, which has been spent by firms. Intangible investment can often be manifested into training. Lifetime employment systems encourage firms to invest in laborers as they are not afraid to experience the loss of investment or proprietary knowledge (Selmer, 2001). Thus, both the firms and labors have responsibility and interest in maximizing the output growth of firms as it can deliver advantages to both of parties (Lincoln \& Nakata, 1997). Selmer stated that a lifetime employment system also creates a benefit by positioning the laborers to gain knowledge and skills by experiencing job rotation through several departments. Job rotation can benefit laborers as they might gain knowledge of the entire production process. The skills and knowledge are accumulated in older labor, and the sense of belonging to firms stimulates the laborers to contribute to management decision (Doeringer, Evans-Klock, \& Terkla, 1998). To conclude, both knowledge and work experience are embedded in aging laborers. As argued by Ilmakunnas and Ilmakunnas (2010), the experience possessed by an older worker can offset or compensate the aging factor, particularly in products industries of chemical, petroleum, rubber, and pharmaceutical that rely highly on R\&D activities that need labors equipped with knowledge (Collinson, 2001). Collinson added that the flourish of $R \& D$ activities also requires experienced labor with a better understanding of the characteristics and the management of the firm. Furthermore, Collinson asserted that older labors not only represent knowledge and management skill but also take part as mentors that can teach and nurture the next generation labors.
Meanwhile, the positive but insignificant coefficient as shown in pharmaceutical products industry has attracted attention on this matter for being different from all capital-intensive industries that show a significant coefficient. In fact, the insignificant coefficient occurred when aging labor continuously increased until 2008, but labor input declined from the 1990s to 2008. Meanwhile, output fluctuated, particularly during the period of the 1990s to 2008. It can be acknowledged then that the insignificant coefficient denotes the effect of macroeconomic conditions and systems built in Japan. The declining trend of output, in addition, was caused by prolonged stagnation in Japan, often referred to as the lost decade. Noted here, Japan's economic miracle starts to fade away and begins facing the decline of output starting in the 1990s, and it has not been easily recovered until now. Both the Asian financial crisis and the rise of fierce global competition have worsened the condition faced by the pharmaceutical products industry. Additionally, the drugs and medicines system built in Japan also contributes to the declining growth of output in pharmaceutical products firms. The delay of drugs and medicinal products delivery and a shortage of pharmaceutical products has, in fact, affected the output generation. This complex condition contributes to the insignificant coefficient among aging labor, labor input, and output in the pharmaceutical products industry in Japan.

\section{Discussion and Conclusion}

As argued by Park and Shin (2012), Asia's aging population is becoming more of a problem and posing challenges to Asian countries. The authors state that although some countries, such as Indonesia, India, The Philippines, Malaysia, and Pakistan, will remain to reap demographic benefits in 2021 to 2030; however, the number of youthful population will eventually get smaller. The findings were also supported by Cameron 
and Cobb-Clark (2005) who found that the populations in several developing countries are aging rapidly. Park and Shin (2012) write, "The average growth rate of per capita labor input was higher than $0.5 \%$ from 1981 to 2007 in Indonesia; the Republic of Korea; Malaysia; Pakistan; Singapore; Taipei China; Thailand; and Vietnam, but it is likely that this trend will be reversed as the populations age" (p. 94). This shows that Asia's growth through its demographic opportunity will weaken as its young population declines rapidly. According to Bloom, Canning, and Fink (2011), the young population had been an important driver for the economic growth of East Asian countries. Thus, the transition of demographic change has significant effects on their industries. However, the experience of industrialized and developed countries only declares inadequate knowledge and information as well as the effect of population aging on developing countries.

What this study has shown is how aging workers in Japan might benefit the industry and which industries might reap the benefit more effectively. A question still remains on what can be learned from Japan's case-particularly for Indonesia as a developing country as it has a very distinctive social, cultural, and political context. Therefore, linking the study result to Indonesia context is important to expand the horizon of knowledge. Notably, Indonesia offers an impressive case study from both the transformation of industrial development and the demographic position. The insights might help the government to manage the imminent demographic transition in hopes of mitigating the downside effect of an aging population on economic growth.

This study emphasizes the role of an external factor-aging labor-in affecting the output generation in Japan. The importance of labor discussion becomes critical as the Japanese are facing a decline of birth rates, higher expectancy life, and an aging labor force. This analysis shows that as Japan becomes more developed, its population and workforce are aging. In 2012, Japan possessed more than $30 \%$ of the aging population (Telegraph, 2014). The rapid emergence of an aging population affects the labor market as the numbers of aging labor are likewise increasing. As it has been confirmed in research findings, aging labor as an external factor not only positively influences the relationship between labor input and output, but also becomes a substantial element in an output analysis.

After going through the challenges caused by the Asian crisis hit of 1997, Indonesia was in a hurry to catch up the pace of economic growth (World Bank, 2007). A strategy for economic growth was not centered on the output of the manufacturing miracle of the 1980s but on multiple extractive commodities, namely rubber, palm oil, and coal (World Bank, 1993). The rampant manufacturing sector in the 1980s experienced the downfall (Bird, 1999). The decline of the manufacturing sector previously becoming the star of industrialization in Indonesia has been starting since 2004. In 2004, the contribution of the manufacturing sector to GDP had been around $27.4 \%$, but this figure fell to $23 \%$ in 2012. According to Didik, an economist from the Institute for Development of Economics and Finance, deindustrialization in Indonesia is a result of a series of failures, ranging from the low competitiveness of local products, high dependency on imported raw materials, low skilled labors and underperforming government in creating supportive policy and regulation (Tempo, 2013). According to Gellert (2010), in his book entitled "Extractive regimes: Toward a better understanding of Indonesian development," de-industrialization in Indonesia needs to be discussed in a context of the rising of the extractive industry through the authorization of extractive regime. This step is crucial to understand Indonesia's developmental trajectory. Geller argued that the shift of industrial structure from manufacturing to extractive brings two 
advantages in one package for the Indonesian government. First, the extractive industry contributes to a substantial portion of the economy as a result of skyrocketing demand and high-reaching international prices. Thus, for more than a decade, the economic growth in Indonesia has been led by the export of extractive industry products, mainly to China for their downstream production. Second, the substantial contribution from extractive commodities serves economic stability, which can last for years or decades. The cohesion of the economy helps to increase the legitimacy and political domination of the ruling regime.

Nonetheless, the rise of the extractive industry has shaped the workforce structure in Indonesia. The domination of the extractive industry and the downfall of the manufacturing sector, on the other hand, reshaped the labor market. An extractive industry targets the most productive age segments, considering the particular employment circumstances. Labor in productive age is more thoroughly chosen as considered being more fit for the job. It is not surprising as the extractive industry is characterized by a highly regulated health and safety environment. Hence, the issues related to age are vigorously emphasized. It, as a result, leads to a drop in labor participation by older laborers as even those who would like to be employed have given up the job search and retired.

At this point in time, the disclosure of aging labor in Indonesia delivers rather insignificant issues in output growth discussion. However, it is noteworthy to explain that the current industrial structure and the demographic position in Indonesia will highly influence the workforce for the next decades. Thus, it is necessary to analyze the change of direction regarding the trend of industry growth and demographic position.

Indonesia has quite a profound situation that is not only derived from the fact that Indonesia is still perceived as a developing country. The age structure of Indonesia's population is peculiar. Indonesia is known for its demographic bonus ${ }^{1}$ as it has an immense number of individuals in the labor force in a productive age group. Believably, the demographic bonus will be a significant resource in exaggerating the economic productivity. On the other side, Indonesia likewise has an increasing number of elderly laborers that, in turn, will have a fundamental effect on the economic situation. In a word, the lower the number of the workforce due to pension schemes, the slower the economic growth. As inferred by Adlakha and Rudolph (1994), Indonesia has the third largest elderly population or people aged over 65 in the world. Moreover, in the period of 1990 to 2025, the number of elderly population in Indonesia is forecasted to grow by $400 \%$. The number of elderly population is $7.8 \%$ out of total population. There are 8 provinces in Indonesia in which the number of elderly population exceeds the other provinces. Those countries include (1) Yogyakarta $(12,48 \%)$; (2) East Java (9.36\%); (3) Central Java (9.26\%); (4) Bali (8.77\%); (5) West Sumatra (8.08\%); (6) North Sulawesi (7.64\%); (7) West Java (7.09\%); and (8) South Sulawesi (6.98\%) (Abikusno, 2005). Further, Abikusno stated that by 2020 the number of elderly population will have been doubled from its current number or doubling to $30-40$ million people.

However, this study demonstrates a prior basis to be believed that aging labor has a number of prominent positive economic effects. As acknowledged in this research, aging labor in Japan positively influences the exaggeration of output growth on knowledgebased industry via the increase of labor input. Certain measures of many countries in EU go a step further in dealing with the aging population. To maximize the potency of aging

\footnotetext{
1 The term of demographic bonus is formed as Indonesia has an opportunity to utilize the big number of working age population.
} 
labor, it is necessary to prolong the period of professional activity. Several countries, such as Belgium, Great Britain, and Austria have issued the legal retirement age or the legal age of leaving the job market for retirement (OECD, 2011). In this case, those countries seek to increase labor productivity through development of certain goods in order to boost the contribution of the elderly population to economic growth (Börsch \& Supan, 2003).

What about Indonesia? According to data from BPS-Susenas conducted in 2007, almost $16 \%$ of the elderly population in Indonesia are educated-indicating that Indonesia has 2.5 million elderly people completing senior high school and university. From the data, it can be understood that Indonesia has 2.5 million elderly people who are qualified as labors. However, this demographic situation is overshadowed by the current industrial structure. According to Suparjan (2010), the unemployment rate in Indonesia is considered high at $8.14 \%$ of the labor force for those whose level of education is low. Fathin, Perdana, Kartikasari, and Sulistyastuti (2014) argue that Indonesia is only able to provide less than $20 \%$ of skilled labors from the required number, and there is inadequate workforce at the managerial level. Understandably, the elderly population may not affect the economic growth, considering the vigor of the elderly population is taken for granted as the key primary industry relies on extractive industries that favor the young labor. United Nations has reported that the policies perceiving elderly population only as unproductive people can lead the skills and knowledge of the older labors to be wasteful. The waste itself derived from the facts that many of them are underemployed, underactive, and more likely to become a drain on a country's resources. Therefore, an understanding of the effect of having an aging population is crucial to the policy development to improve the efficacy of labor market in Indonesia.
Börsch and Supan (2003) offered a solution to carry through the elderly population problem by focusing on the exploitation of human capital and by facilitating that human capital on a structural adjustment. According to Börsch and Supan, a country needs to develop their human capital for their industrial needs. In addition to that, Colonia-Willner (1998) stated that aging labor has immense tacit knowledgeprocedural knowledge to cope with daily problems. Tacit knowledge itself tends not to decline with older age. Further, Colonia and Willner argued that tacit knowledge becomes the reasoning for why many older managers can perform as well as younger ones. Therefore, it is necessary for the Indonesian Government to rebuild the industrialization by putting the basis upon human capital for knowledgeintensive industry throughout the country. According to this scenario, the concept of lifetime employment will be suitable to apply in this industry. By applying this policy, it is possible for Indonesia to exploit a large number of educated elderly populations.

Further, Indonesia's Government also needs to pass the law against employers discriminating against the elderly people. This policy definitely will affect the retirement system and values. Consecutively, it will also overall effect a labor market condition. Considering that the size of productivity and economic activity are declining due to the earlier-retirement scheme and the rise of elderly population, prolonging the retirement age might be a solution to overcome potential labor shortages-particularly to increase domestic participation rate.

For the firms or industries that have hired aging labors, it is clear that many attempts have been devoted to finding a way to boost the output. Finding out how to increase output is what firms' executives are trying hard to do. This study offers evidence that the knowledge acquired by aging laborer over their lifetime can positively influence the output level in 
capital-intensive industries. Concurrently, the result of this study has an implication to output management. This study provides acknowledgment for firms' executives to decide what kinds of policies that need to be designed for the output enhancement. Thus, the information presented is not restricted to academia and policymakers, but it can give substantial support for firms' executives in Indonesia in managing the output at a satisfactory level.

\section{References}

Abdel-Wahab, M., \& Vogl, B. (2011). Trends of productivity growth in the construction industry across Europe, US and Japan. Construction Management and Economics, 29(6), 635-644.

Abikusno, N. (2005). The elderly in Indonesia: Current policy and programmes. Bold, 15(2), 18-22.

Adlakha, A., \& Rudolph, D. J. (1994). Aging trends: Indonesia. Cross-Cultural Gerontology, 9(1), 99-108.

Aigner, D. J., \& Chu, S. F. (1968). On estimating the industry production function. The American Economic Review, 58(4), 826-839.

Armstrong, J. S. (2011). Illusions in Regression Analysis. Retrieved from http://repository. upenn.edu/marketing_papers/173.

Beaudry, P., Colard, F., \& Green, D. A. (2005). Demographics and recent productivity performance: Insights from cross-country comparisons. Canadian Journal of Economics, 38(3), 309-344.

Beck, N., \& Katz, J. N. (1995). What to do (and not to do) with time-series cross-section data. American Political Science Review, 89(3), 634-647.

Becker, G. S. (1962). Investment in human capital: a theoretical analysis. The Journal of Political Economy, 70(5), 9-49.

Bird, K. (1999). Concentration in Indonesia manufacturing 1975-93. Bulletin of Indonesian Economic Studies, 35(1), 43-73.
Bloom, D. E., Canning, D., Fink, G. (2011). Implications of population aging for economic growth (Working paper No. 16705). Cambrige, MA: National Bureau of Economic Research. doi:10.3386/w16705bg Börsch, \& Supan, A. (2003). Labor market effects of population aging. Labour, 17(s1). doi: https://doi.org/10.1111/1467-9914.17. specialissue. 2

Bureau of Labor Statistics, T. (2012). BLS projections for the US labor market for 20102020. Retrieved from U.S.:

Cameron, L., \& Cobb-Clark, D. A. (2005). Do co-residency with and financial transfers from children reduce the need for elderly parents to work in developing countries?. Retrieved from https://www.cbe.anu.edu. au/researchpapers/cepr/DP508.pdf

Carree, M. A., Klomp, L., \& Thurik, A. R. (2000). Productivity convergence in OECD manufacturing industries. Economics Letters, 66(3), 337-345.

Chatterjee, S., Hadi, A. S., \& Price, B. (2000). Regression analysis by example (Vol. 3). New York: John Wiley \& Sons.

Christiaans, T. (2003). Aging in a neoclassical theory of labor demand. Retrieved from http:// hdl.handle.net/10419/83188

Cobb, C. W., \& Douglas, P. H. (1928). A theory of production. The American Economic Review, 18(1), 139-165.

Coccia, M. (2009). What is the optimal rate of $R$ $\& \mathrm{D}$ investment to maximize productivity growth?. Technological Forecasting and Social Change, 76(3), 433-446.

Collinson, S. (2001). Developing and deploying knowledge for innovation: British and Japanese corporations compared. International Journal of Innovation Management, 5(1), 73-103.

Colonia-Willner, R. (1998). Practical intelligence at work: Relationship between aging and cognitive efficiency among managers in a bank environment. Psychology and Aging, 12(1), 45-57. 
Disney, R., Haskel, J., \& Heden, Y. (2003). Restructuring and productivity growth in UK manufacturing. The Economic Journal, 113(489), 666-694.

Doeringer, P. B., Evans-Klock, C., \& Terkla, D. G. (1998). Hybrids or hotchpotches? Workplace practices of Japanese and domestic startups in the United States. Industrial and Labor Relations Review, 51(2), 171-186.

Douglas, P. H. (1976). The Cobb-Douglas production function once again: Its history, its testing, and some new empirical values. Journal of Political Economy, 84(5), 903-916.

Fathin, C. A., Perdana, A. B., Kartikasari, A., \& Sulistyani, D. R. (2014). Indonesian human resources readiness in term of facing the ASEAN economic community. Jurnal Ilmu Sosial dan Ilmu Politik, 18(2), 81-98.

Feyrer, J. (2007). Demographics and productivity. The Review of Economics and Statistics, 89(1), 100-109.

Gellert, P. K. (2010). Extractive regimes: Towards a better understanding of Indonesian development. Rural Sociology, 75(1), 28-57.

Gelman, A., \& Hill, J. (2007). Data analysis using regression and multilevel/hierarchical models. New York: Cambridge University Press.

Gray, M. (2004). The social construction of the service sector: Institutional structures and labour market outcomes. Geoforum, 3(5), 23-34.

Gujarati, D. (2006). Essentials of econometrics 3rd edition. New York: Macmillan Publishing Company.

Ilmakunnas, P., \& Ilmakunnas, S. (2010). Work force ageing and expanding service sector: A double burden on productivity?. The Service Industries Journal, 30(12), 2093-2110.

Imagawa, T. (2008). Trade and labor productivity effects on the changing structure of employment in Japan. Paper presented at the 16th Inforum World Conference, University of Lefke.

Ito, K., \& Lechevalier, S. (2009). The evolution of the productivity dispersion of firms: A reevaluation of its determinants in the case of Japan. Review of World Economics, 145(3), 405-429.

Krugman, P. (1994). The Myth of Asia's Miracle. Foreign Affairs, 73(6), 62-78.

Lincoln, J. R., \& Nakata, Y. (1997). The transformation of the Japanese employment system nature, depth and origins. Work and Occupations, 24(1), 33-55.

Malmberg, B., Lindh, T., \& Halvarsson, M. (2008). Productivity consequences of workforce aging: Stagnation or Horndal effect?. Population and Development Review, 34, 238-256.

OECD, T. (2011). Trends in retirement and in working at older ages, in pensions at a glance 2011: Retirement-income systems in OECD and G20 countries. Retrieved from http:// dx.doi.org/10.1787/pension_glance-2011-6-en

Park, D., \& Shin, K. (2012). Impact of population aging on Asia's future growth. In P. Donghyu., S.-H. Lee, \& A. Mason (Eds.), Aging, Economic Growth, and Old-Age Security in Asia (pp. 83-110). The Philippines: Asian Development Bank.

Prskawetz, A. (2006). The impact of population ageing on innovation and productivity growth in Europe. Retrieved from http://pure.iiasa. ac.at/id/eprint/7714/

Prskawetz, A., Fent, T., \& Guest, R. (2008). Workforce aging and labor productivity: The role of supply and demand for labor in the G7 countries. Population and Development Review, 34, 298-323.

Remery, C., Henkens, K., Schippers, J., \& Ekamper, P. (2003). Managing an aging workforce and a tight labor market: Views held by Dutch employers. Population Research and Policy Review, 22(1), 21-40.

Sato, R. (1970). The estimation of biased technical progress and the production function. International Economic Review, 11(2), 179-208.

Selmer, J. (2001). Human resource management in Japan: Adjustment or transformation?. 
International Journal of Manpower, 22(3), 235-243.

Shephard, R. J. (2000). Aging and productivity: Some physiological issues. International Journal of Industrial Ergonomics, 25(5), 535545 .

Silverstein, M. (2008). Meeting the challenges of an aging workforce. American Journal of Industrial Medicine, 51(4), 269-280.

Skirbekk, V. (2004). Age and individual productivity: A literature survey Vienna yearbook of population research (Vol. 2). Vienna: Vienna Institute of Demography of the Austrian Academy of Sciences.

Skirbekk, V. (2008). Age and productivity potential: A new approach based on ability levels and industry-wide task demand. Population and Development Review, 34, 191207.

Souma, W., Ikeda, Y., Iyetomi, H., \& Fujiwara, Y. (2009). Distribution of labour productivity in Japan over the period 1996-2006. Economics, 3(22), 1-17.

Solow, R. M. (1956). A contribution to the theory of economic growth. Quarterly Journal of Economics, 70, 65-94.

Statistic Bureau of Japan, T. (2012). Retrieved from http://www.stat.go.jp/english/data/ handbook/c02cont.htm

Suparjan. (2010). Jaminan sosial berbasis komunitas: Respon atas kegagalan Negara dalam penyediaan jaminan kesejahteraan. Jurnal Ilmu Sosial dan Ilmu Politik, 13(3), 249-274.

Swan, T. W. (1956). Economic growth and capital accumulation. Economic Record, 32, 334-361.
Tang, J., \& MacLeod, C. (2006). Labour force ageing and productivity performance in Canada. Canadian Journal of Economics, 39(2), 582-603.

Tangen, S. (2002). Understanding the concept of productivity. Paper presented at the 7 th Asia-Pacific Industrial Engineering and Management Systems Taipei.

Telegraph, T. (2014). World faces ageing population time bomb says UN. Retrieved from http://www.telegraph.co.uk/news/ worldnews/asia/japan/9579950/Worldfaces-ageing-population-time-bomb-saysUN.html

Tempo. (2013). Indonesia Trapped in Deindustrialization: Indef. Retrieved from http://en.tempo.co/read/ news/2013/11/08/056528018/IndonesiaTrapped-in-De-industrialization-Indef

Timmer, M. P. (2002). Climbing the technology ladder too fast? New evidence on comparative productivity performance in Asian manufacturing. Japanese and International Economies, 16(1), 50-72.

Verhaegen, P., \& Salthouse, T. A. (1997). Meta-analyses of age-cognition relations in adulthood: Estimates of linear and nonlinear age effects and structural models. Psychological Bulletin, 122(3), 231-249.

World Bank, T. (1993). The East Asian miracle: Economic growth and public policy. New York: Oxford University Press.

World Bank, T. (2007). 10 years after the crisis, special focus: Sustainable development in East Asia's urban fringe. Retrieved from http://documents.worldbank.org/curated/ en/679431468038153232/pdf/393720EAP1 Update1April200701PUBLIC1.pdf 